\title{
Risk factors for bacterial vaginosis among Indonesian women
}

\author{
Dwiana Ocviyanti, ${ }^{1}$ Yeva Rosana, ${ }^{2}$ Shanty Olivia, ${ }^{1}$ Ferry Darmawan ${ }^{1}$ \\ ${ }^{1}$ Department of Obstetry and Gynecology, Faculty of Medicine University of Indonesia \\ ${ }^{2}$ Department of Microbiology, Faculty of Medicine University of Indonesia
}

\begin{abstract}
Abstrak
Tujuan Untuk mengetahui faktor-faktor risiko bakterial vaginosis (BV) pada perempuan Indonesia.

Metode Penelitian ini merupakan studi deskriptif potong lintang yang melibatkan 492 perempuan yang berusia 1550 tahun. Sekret vagina diambil kemudian dilakukan tes Whiff dan tes Nugent untuk mengetahui ada atau tidaknya BV. Tempat penelitian adalah Puskesmas Karawang, Pedes, Cikampek, Tempuran, Klinik Batalyon 201 Cijantung, Fakultas Kedokteran Universitas Indonesia dan Rumah Sakit Cipto Mangunkusumo.

Hasil Subjek memiliki usia 15-25 tahun (26,8\%), 26 - 40 tahun (59,1\%), ᄀ> 40 tahun (14\%). Usia rata-rata adalah 30.9 tahun. Status pernikahan subjek adalah belum menikah (16,9\%), menikah $1 x(76,4 \%)$, dan menikah $>1 x$ (6,7\%). Prevalensi bakterial vaginosis pada penelitian ini adalah $30.7 \%$ sesuai dengan skor Nugent. Usia $>40$ tahun $(O R=3,1595 \% C I=1,15-1,48)$ dan pasangan yang tidak disirkumsisi $(O R=6,25,95 \% C I=2,54-15,38)$ merupakan faktor determinan yang secara signifikan berpengaruh terhadap kejadian $B V(p<0,05)$.
\end{abstract}

Kesimpulan Prevalensi BV pada penelitian ini adalah 30,7\%. Faktor risiko BV adalah usia dan pasangan yang tidak disirkumsisi. (Med J Indones 2010; 19:130-5)

\begin{abstract}
Aim To identify risk factors for bacterial vaginosis (BV) among Indonesian women.

Methods This is a cross sectional study involving 492 women with age ranged 15-50 years. Vaginal discharge was collected. Whiff test and Nugent scoring were utilized to identify BV. Settings are Puskesmas Karawang, Pedes, Cikampek,Tempuran, Batalyon 201 Clinic Cijantung, Faculty of Medicine University of Indonesia and Cipto Mangunkusumo Hospital.

Results Age of the subjects were 15-25 years old (26,8\%), 26 - 40 years old $(59,1 \%)$, and $>40$ years old $(14 \%)$. The mean age was 30.9 years. Marital status of the subjects were not-married (16,9\%), married (76,4\%), married more than once (6,7\%). Prevalence of bacterial vaginosis in this study was $30.7 \%$ according to Nugent's score. Age $>40$ years old $(\mathrm{OR}=3,15$ IK $95 \%=1,15-1,48)$ and uncircumcised couple $(\mathrm{OR}=6,25, \mathrm{IK} 95 \%=2,54-15,38)$ were independently and significantly associated with incidence of BV $(\mathrm{p}<0.05)$

Conclusions Prevalence of BV in this study was $30.7 \%$. Determinant risk factors of BV were age and uncircumcised sexual partner. (Med J Indones 2010; 19:130-5)
\end{abstract}

Key words: bacterial vaginosis, risk factors, vaginal flora

Bacterial vaginosis $(\mathrm{BV})$ is one of the most common etiologies of gynecologic complaint. ${ }^{1,2} \mathrm{BV}$ is caused by an imbalance of normal vaginal flora, allowing diseasecausing bacteria. Lactobacillus sp, the normal vaginal flora, is replaced by facultative anaerobic bacteria including Mobiluncus species, Bacteroides species, especially Gardnerella vaginalis, to predominate. ${ }^{3,4}$

The prevalence of BV and morphotype distribution varies among the world population. Some research reported that the prevalence of BV was high among African, Afro-American dan Afro-Caribian population. ${ }^{5}$ Research among Asian women in India and Indonesia reported that prevalence of BV was about $32 \% .{ }^{6,7}$

$\mathrm{BV}$ is associated with some morbidity in women include urinary tract infections, pelvic inflammatory disease, Correspondence email to: dwianaocviyanti@yahoo.com premature rupture of membranes, preterm labor, and increased risk of HIV transmission. ${ }^{8-11}$ prevention strategies are needed to reduce the incidence of BV. Identification of risk factors is one important precaution effort

The socio-economic risk factors which parameters are income and education level associated with BV. ${ }^{12,13}$ Research on other risk factors associated with BV had been carried out in some countries. the study population was small and very selective that did not describe the population in general. In Indonesia, there were no data about the study of risk factors for BV. This research was conducted to identify risk factors for BV among Indonesian women so that a prevention strategy can be made. 


\section{METHODS}

This is a descriptive study conducted in Puskesmas Karawang, Pedes, Cikampek, Tempuran (District Karawang), Klinik Batalyon 201 Cijantung and Laboratory of Microbiology, Faculty of Medicine University of Indonesia in the period of May 2008 February 2009. With a consecutive sampling technique, 492 samples were obtained from the population of Indonesian women aged 15-50 years. It was already arranged that 100 samples would be obtained from each location, but actually 8 of the subject had to be excluded because the laboratory result could not be read. The data collection mechanism is as follows:

1. Interviews and questionnaires to determine the distribution of demographic and medical characteristics data

Demographic characteristic data of age, education, employment, and marital status were recorded. Recorded medical characteristic data were parity, reproductive tract complaints, history of Diabetes Mellitus, history of sexually transmitted diseases, use of antibiotics, use of contraception, husband circumcision status, use of panty liners, and use of vaginal soap.

2. Whiff test for BV detection

The procedures of Whiff test are taking a vaginal discharge, putting 1-2 drops of it on an object glass and mixing with $1-2$ drops of $5-10 \% \mathrm{KOH}$ by wooden stick under the nose. Thus the examiner smells the presence of fishy-like odor. Whiff test is positive if the fishy-like odor is present. For notmarried subjects, vaginal discharge was taken with cotton buds from distal two-third portion of vagina outside the hymen.
3. Nugent scoring system for BV diagnosis Gram-stained preparatory was assessed and scored based on the Nugent Criteria (Table 1) ) $^{14}$

Nugent's diagnostic criteria are based on combined score $(\mathrm{A}+\mathrm{B}+\mathrm{C})$. The diagnosis is normal (score $0-3$ ), indeterminate (score 4-6), and BV (score $\geq 7$ ). In this study, BV categorized into two diagnoses: positive (score $\geq 7$ ) and negative (score is normal or indeterminate).

Data analysis was done using SPSS 16. Chi square and Fischer exact test were used for bivariate analysis to know the difference of BV's prevalence among each variable. Multivariate analysis was done using logistic regression to know some factors associated with BV.

\section{RESULTS}

\section{Demographic characteristic}

There were 492 women involved in this study. The average age were $30.9+0.27$ years old, consisted of $15-25$ years old $(26,8 \%), 26-40$ years old $(59,1 \%)$, and $>40$ years old $(14 \%)$. Marital status of subjects were not married $(16,9 \%)$, married $(76.4 \%)$, and married more than once $(6,7 \%)$. All subjects $>40$ years old were married or married $>1$. Most subjects occupation was housewife $(69.2 \%)$ and education level was high school $(46.3 \%)$. BV was found in 151 women $(30.7 \%)$. Among demographic characteristics, factors related to the prevalence of BV were age, education, and occupation $(\mathrm{p}<0.05)$. Marital status did not have a relationship with the prevalence of $\mathrm{BV}$.

Table 1. Gram-staining Scoring System

\begin{tabular}{cccc}
\hline Score & $\begin{array}{c}(\mathrm{A}) \\
\text { Lactobacillus } \\
\text { Morphotypes }\end{array}$ & $\begin{array}{c}\text { (B) } \\
\text { Gardnerella and Bacteroides spp. } \\
\text { Morphotypes }\end{array}$ & $\begin{array}{c}\text { Curved-gram variable rods } \\
\text { Morphotype }\end{array}$ \\
\hline 0 & $4+$ & 0 & 0 \\
1 & $3+$ & $1+$ & $1+$ or 2+ \\
2 & $2+$ & $3+$ & $3+$ or $4+$ \\
3 & $1+$ & $4+$ & \\
4 & 0 & & \\
\hline
\end{tabular}

Morphotype scoring is based on the number per field of view. 0 , no morphotypes present; $1+,<1$ morphotype present; $2+, 1$ to 4 morphotypes present; $3+, 5$ to 30 morphotypes present; 4+, >30 morphotypes present 
Table 2. Demographic characteristics and prevalence of BV

\begin{tabular}{|c|c|c|c|}
\hline Demographic characteristics & $\mathbf{n}(\%)$ & $\begin{array}{l}\text { BV+ } \\
\text { n(\%) } \\
\end{array}$ & p value \\
\hline \multicolumn{4}{|l|}{ Age (years old) } \\
\hline $15-25$ & $132(26,8)$ & $18(13,6)$ & Ref \\
\hline $26-40$ & $291(59,1)$ & $98(33,7)$ & 0,000 \\
\hline$\geq 40$ & $69(14,0)$ & $35(50,7)$ & 0,000 \\
\hline \multicolumn{4}{|l|}{ Marital status } \\
\hline Not married & $83(16,9)$ & $0(0)$ & NS \\
\hline Married & $376(76,4)$ & $138(36,7)$ & \\
\hline Married $>1$ & $33(6,7)$ & $13(39,4)$ & \\
\hline \multicolumn{4}{|l|}{ Education level } \\
\hline Elementary & $75(13,0)$ & $23(35,9)$ & 0,008 \\
\hline Junior high & $74(15,0)$ & $26(35,1)$ & 0,008 \\
\hline Senior high & $228(46,3)$ & $79(34,6)$ & 0,001 \\
\hline$\geq$ Senior high & $126(25,6)$ & $23(18,2)$ & Ref \\
\hline \multicolumn{4}{|l|}{ Occupation } \\
\hline Housewife & $340(69,1)$ & $94(27,6)$ & 0,007 \\
\hline Student & $71(14,4)$ & $20(28,2)$ & 0,027 \\
\hline Others & $81(16,5)$ & $37(45,7)$ & Ref \\
\hline
\end{tabular}

Note

Ref: reference

NS: not significant

\section{Medical characteristics}

Women with parity $>5$ were more prone to of BV compared to nullipara (50\% vs $2.4 \%, \mathrm{p}=0.005)$ and parity $1-5(36.9 \%, \mathrm{p}=0.000)$. The prevalence of BV was higher among women with uncircumcised spouse compared to women with circumcised spouse $(36.9 \%$ vs $6.8 \%, \mathrm{p}=0.000)$. The prevalence of BV was also high among women using panty liners $(\mathrm{p}=0.012)$ (Table 2$)$. Despite its statistic significance, it was found that the prevalence of BV was higher among women not using any contraception. History of diabetes mellitus (DM), sexual transmitted infections (STIs), use of antibiotics, and use of vaginal soap had no significant correlation with the incident BV.

\section{Multivariate analysis}

Age, education, occupation, parity, circumcised spouse and use of panty liners were included in multivariate analysis (Table 4). Based on the analysis, it is found that age above 40 years $(\mathrm{OR}=3.15, \mathrm{p}=0.003)$ and uncircumcised spouse $(\mathrm{OR}=6.25, \mathrm{p}=0.00)$ were the independent factor associated with BV. Other factors included in this multivariate analysis did not have significant correlation to $\mathrm{BV}$. 
Table 3. Medical characteristics and prevalence of BV

\begin{tabular}{|c|c|c|c|}
\hline Medical characteristic & n (\%) & $\mathrm{BV}+\mathbf{n}(\%)$ & $p$ value \\
\hline \multicolumn{4}{|l|}{ Parity } \\
\hline 0 & $118(24)$ & $12(2.4)$ & Ref \\
\hline $1-5$ & $366(74,4)$ & $135(36.9)$ & 0,000 \\
\hline$>5$ & $8(1,6)$ & $4(50)$ & 0,005 \\
\hline \multicolumn{4}{|l|}{ History of DM } \\
\hline Yes & $1(0,2)$ & $0(0)$ & NS \\
\hline No & $491(99,8)$ & $2(0,4)$ & \\
\hline \multicolumn{4}{|l|}{ Unknown } \\
\hline \multicolumn{4}{|l|}{ History of STIs } \\
\hline Yes & $10(2,0)$ & $134(30.5)$ & NS \\
\hline No & $439(89,2)$ & $3(30)$ & \\
\hline Unknown & $43(8,7)$ & $14(32.5)$ & \\
\hline \multicolumn{4}{|l|}{ Use of antibiotics } \\
\hline Yes & $9(1,8)$ & $147(30.4)$ & NS \\
\hline No & $483(98,2)$ & $4(44.4)$ & \\
\hline \multicolumn{4}{|l|}{ Use of contraception } \\
\hline Yes & $259(52,6)$ & $55(21,2)$ & NS \\
\hline Hormonal/Combination & $89(34,4)$ & $30(33.7)$ & \\
\hline Progesterone & $145(55,9)$ & $25(17.2)$ & \\
\hline Condom/IUD & $25(9,7)$ & $0(0)$ & \\
\hline $\mathrm{No} /$ sterile & $233(47,4)$ & $96(41,2)$ & \\
\hline \multicolumn{4}{|l|}{ Circumcised spouse } \\
\hline Yes & $390(79,3)$ & $7(6.8)$ & Ref \\
\hline No & $102(20,7)$ & $144(36.9)$ & 0,000 \\
\hline \multicolumn{4}{|l|}{ Use of panty liners } \\
\hline Yes & $68(13,8)$ & $139(32.8)$ & 0,012 \\
\hline No & $424(86,1)$ & $12(17.6)$ & Ref \\
\hline \multicolumn{4}{|l|}{ Use of vaginal soap } \\
\hline Yes & $188(38,2)$ & $99(32.6)$ & NS \\
\hline No & $304(61,8)$ & $52(27.6)$ & \\
\hline
\end{tabular}

Note:

Ref: reference

NS: not significant

Table 4. Factors affecting prevalence of BV

\begin{tabular}{|c|c|c|}
\hline Risk factor & OR (95\% CI) & $p$ value \\
\hline \multicolumn{3}{|l|}{ Age (years old) } \\
\hline $15-25$ & 1,00 & Ref \\
\hline $26-40$ & $1,34(0,70-2,57)$ & NS \\
\hline$\geq 40$ & $3,15(1,15-1,48)$ & 0,003 \\
\hline \multicolumn{3}{|l|}{ Education } \\
\hline Elementary & $0,70(0,32-1,56)$ & NS \\
\hline Junior high & $0,83(0,39-1,79)$ & NS \\
\hline Senior high & $0,90(0,47-1,72)$ & NS \\
\hline$\geq$ Senior high & 1,00 & Ref \\
\hline \multicolumn{3}{|l|}{ Occupation } \\
\hline House wife & $1,85(0,47-1,55)$ & NS \\
\hline Student & $1,45(0,71-2,96)$ & NS \\
\hline Other & 1,00 & Ref \\
\hline \multicolumn{3}{|l|}{ Parity } \\
\hline 0 & 1,00 & Ref \\
\hline $1-5$ & $1,88(0,87-4,09)$ & NS \\
\hline$>5$ & $2,53(0,49-13,02)$ & NS \\
\hline Uncircumcised spouse & $6,25(2,54-15,38)$ & 0,000 \\
\hline Use of panty liner & $0,97(0,46-2,06)$ & NS \\
\hline
\end{tabular}

Note

Ref: reference

NS: not significant 


\section{DISCUSSION}

Based on multivariate analysis, determinant risk factors for BV were age above 40 years old and with an uncircumcised spouse.

An Uncircumcised spouse was the most significant independent risk factor for $\mathrm{BV}(\mathrm{OR}=6.25,95 \% \mathrm{CI}=$ 2,54-15,38). Circumcisions are related to the hygiene of penis which is associated with the transmission of infection. Because mucosal membrane of preputium is less keratinized than exposed skin, it is prone to trauma during intercourse and became a pathway for pathogens. The space between preputium and glans penis is a moist and warm environment conducive for discharge and pathogen deposit. ${ }^{15,16}$ Gray, et.al has reported that circumcised spouse reduced the risk of genital ulcers, Trichomonas, and BV in his partner. Yang and his colleagues also stated that circumcision reduces the risk of sexually transmitted infections including human immunodeficiency virus (HIV), human papilloma virus (HPV), herpes simplex virus (HSV) type 2, and syphilis. ${ }^{17}$

Age above 40 years old was risk factor for $\mathrm{BV}(\mathrm{OR}=$ $3.15, p=0.003$ ). It is associated with the perimenopausal hypoestrogenic condition at that age. Declining levels of estrogen causes elevated vaginal $\mathrm{pH} .{ }^{18}$ This condition is not optimal for Lactobacillus sp growth as the dominant normal vaginal flora but very conducive for the growth of microorganisms causing BV. ${ }^{19}$ Research on women aged $>40$ years conducted by Cauci et al found that perimenopausal women had higher BV prevalence than fertile women and post-menopause and that Lactobacillus $s p$ level decreased with age. ${ }^{20}$

There is an interesting finding in the characteristics of contraceptive use. Despite its statistic significance, women using contraception had lower risk for BV than women not using contraception or sterile. More detailed research is needed to identify contraception as risk factor for $\mathrm{BV}$.

In conclusion, The prevalence of BV by Nugent criteria in this study was $30.7 \%$. Factors associated with BV incidence were age, education, occupation, parity, uncircumcised spouse and use of panty liners. Based on the multivariate analysis, determinant risk factors for BV were age and uncircumcised spouse.

\section{Acknowledgments}

Authors thanks directors and staffs of RSU Karawang and Puskesmas Karawang, directors and staffs Klinik
Batalyon 201 Cijantung, and all parties who contributed to this research.

\section{REFERENCES}

1. Baisley K, Changalucha J, Weiss HA, Mugeye K, Everett $\mathrm{D}$, Hambleton I, et al. Bacterial vaginosis in female facility workers in north-western Tanzania: prevalence and risk factors. Sex Transm Infect. 2009;85:370-5.

2. Tolosa JE, Chaithongwongwatthana S, Daly S, Maw WW, Gaitn H, Lumbiganon P, et al. The International Infections in Pregnancy (IIP) study: Variations in the prevalence of bacterial vaginosis and distribution of morphotypes in vaginal smears among pregnant women. American Journal of Obstetrics and Gynecology 2006;195:1198-204.

3. Yan DH, Lu Z, Su JR. Comparison of main lactobacillus species between healthy women and women with bacterial vaginosis. Chin Med J (Engl). 2009;122:2748-51.

4. Thorsen P, Jensen IP, Jeune B, et al. Few microorganisms associated with bacterial vaginosis may constitute the pathologic core: a population-based microbiologic study among 3596 pregnant women. Am J Obstet Gynecol. 1998;178:580-7

5. Livengood CH. Bacterial vaginosis: an overview for 2009. Rev Obstet Gynecol. 2009;2:28-37.

6. Bhalla P, Chawla R, Garg S, Singh MM, Raina U, Bhalla $\mathrm{R}$, et al. Prevalence of bacterial vaginosis among women in Delhi, India. Indian J Med Res. 2007;125:167-72.

7. Joesoef MR, Karundeng A, Runtupalit C, Moran JS, Lewis JS, Ryan CA. High rate of bacterial vaginosis among women with intrauterine devices in Manado, Indonesia. Contraception. 2001;64:169-72.

8. Klebanoff MA, Hillier SL, Nugent RP, MacPherson CA, Hauth JC, Carey JC, et al. Is bacterial vaginosis a stronger risk factor for preterm birth when it is diagnosed earlier in gestation? Am J Obstet Gynecol. 2005;192:470-7.

9. Myer L, Kuhn L, Stein ZA, Wright J, Denny L. Intravaginal practices, bacterial vaginosis, and women's susceptibility to HIV infection: epidemiological evidence and biological mechanisms. The Lancet Infectious Diseases. 2005;5:786-94.

10. Peipert JF, Montagno AB, Cooper AS, Sung CJ. Bacterial vaginosis as a risk factor for upper genital tract infection, Am J Obstet Gynecol. 1997;177:1184-7.

11. Harmanli OH, Cheng GY, Nyirjesy P, Chatwani A, Gaughan JP. Urinary tract infections in women with bacterial vaginosis. Obstetrics \& Gynecology. 2000;95:710-2.

12. Patel V, Weiss HA, Kirkwood BR, Pednekar S, Nevrekar $\mathrm{P}$, Gupte $\mathrm{S}$, et al. Common genital complaints in women: the contribution of psychosocial and infectious factors in a population-based cohort study in Goa, India. Int J Epidemiol. 2006;35:1478-85.

13. Rauh VA, Culhane JF, Hogan VK. Bacterial vaginosis : a public health problem for women. JAMWA. 2000;55: 220-4

14. Ledger WJ, Witkin SS. Diagnosis of Vulvovaginal Disease. In: Vulvovaginal Infections. London: Manson Publishing Ltd. 2007:16-24.

15. Sahasrabuddhe VV, Vermund SH. The future of HIV prevention: Control of sexually transmitted infections and 
circumcision interventions. Infectious Disease Clinics of North America. 2007;21:241-57.

16. Hankins C. Male circumcision: implications for women as sexual partners and parents. Reprod Health Matters. 2007; 15:62-7

17. Yang SS-D, Hsieh CH, Chang SJ. Effects of circumcision on urinary tract nfection and sexually transmitted disease. Tzu Chi Medical Journal. 2009;21:185-9.

18. Gorodeski GI, Hopfer U, Liu CC, Margles E. Estrogen acidifies vaginal $\mathrm{pH}$ by up-regulation of proton secretion via the apical membrane of vaginal-ectocervical epithelial cells. Endocrinology. 2005;146:816-24.
19. Galhardo CL, Soares JM, Jr. Simoes RS, Haidar MA, Rodrigues de LG, Baracat EC. Estrogen effects on the vaginal $\mathrm{pH}$, flora and cytology in late postmenopause after a long period without hormone therapy. Clin Exp Obstet Gynecol. 2006;33:85-9.

20. Cauci S, Driussi S, De SD, Penacchioni P, Iannicelli T, Lanzafame $\mathrm{P}$, et al. Prevalence of bacterial vaginosis and vaginal flora changes in peri- and postmenopausal women. J Clin Microbiol. 2002;40:2147-52. 